\title{
A New Maximum Size Record of the Shi Drum (Umbrina cirrosa Linnaeus, 1758) for Aegean Sea
}

\author{
Ö. Cengiz ${ }^{a *}$ (D) and Ş. Ş. Paruğ $\breve{g}^{b}$ (D) \\ ${ }^{a}$ Faculty of Fisheries, Van Yüzüncü Y1l University, Van, Turkey \\ ${ }^{b}$ Faculty of Fisheries, Kastamonu University, Kastamonu, Turkey \\ *e-mail: ozgurcengiz17@gmail.com
}

Received: December 02, 2019 - Accepted: January 13, 2020 - Distributed: May 31, 2021

(With 2 figures)

\begin{abstract}
The present study has been conducted to find out new findings on maximum length and weight values of Umbrina cirrosa in the Bay of Saros (Northern Aegean Sea, Turkey). On September, 11, 2016, a single specimen of Umbrina cirrosa with $68.8 \mathrm{~cm}$ total length and $2600.00 \mathrm{~g}$ total weight was caught by handline at a depth of $20 \mathrm{~m}$. The provable size is the second largest length ever reported in the all seas of the world
\end{abstract}

Keywords: Umbrina cirrosa, shi drum, maximum length, Aegean Sea.

\section{Um novo registro de tamanho máximo do corvina (Umbrina cirrosa Linnaeus, 1758) para o Mar Egeu}

\section{Resumo}

O presente estudo foi realizado para descobrir novas descobertas sobre os valores máximos de comprimento e peso de Umbrina cirrosa na Baía de Saros (Mar Egeu do Norte, Turquia). Em 11 de setembro de 2016, um único espécime de Umbrina cirrosa com $68.8 \mathrm{~cm}$ de comprimento total e $2600.00 \mathrm{~g}$ de peso total foi capturado por linha de mão a uma profundidade de $20 \mathrm{~m}$. O tamanho provável é o segundo maior comprimento já registrado em todos os mares do mundo.

Palavras-chave: Umbriba cirrosa, corvina, tamanho máximo, Mar Egeu.

\section{Introduction}

The shi drum (Umbrina cirrosa Linnaeus, 1758) is a demersal marine species feeding on bottom invertebrates and usually living on rocky and sandy bottoms in coastal waters to a depth of about $100 \mathrm{~m}$. It is distributed in Bay of Biscay and Gibraltar to southern Morocco, including the Mediterranean, Black Sea and Sea of Azov (Froese and Pauly, 2019).

Maximum length and weight are quite important theoretical parameters in fisheries science (Dulčić and Soldo, 2005). Directly and indirectly, these measurements enter in most of the models used in stock assessments (Borges, 2001). For these reasons, updating information about the maximum size of a species that might be commercially or recreationally exploited in the future gains importance (Navarro et al., 2012). This study presents the provable size is the second largest length ever reported in the all seas of the world.

\section{Material and Methods}

The Bay of Saros, which is situated in the Northeastern Aegean Sea, is connected to the North Aegean with a depth of approximately $600 \mathrm{~m}$ to the west. The shelf extends at a water depth of $90-120 \mathrm{~m}$. The length of the bay is about $61 \mathrm{~km}$ and the width at the opening to the Aegean Sea is about $36 \mathrm{~km}$ (Eronat and Sayin, 2014). As Bay of Saros had been closed to bottom trawl fishing since 2000 (Cengiz et al., 2014; 2015) and no industrial activity was prevalent in the area (Sari and Çağatay, 2001), the bay can be considered as a pristine environment (Cengiz et al., 2013).

A single specimen of $U$. cirrosa was caught in Bay of Saros (Figure 1) with handline by a commercial fisherman from $20 \mathrm{~m}$ depth on September, 11, 2016.

Total length is defined as the measurement taken from the anterior-most part of the fish to the end of the caudal fin rays when compressed dorso-ventrally (Anderson and Gutreuter, 1983). Hereby, the specimen was subsequently measured to the nearest $\mathrm{mm}$ and weighted to the nearest g. Unfortunately, the specimen was not preserved as it was sold by a professional fisherman at the fish market.

\section{Results and Discussion}

On September, 11, 2016, a single specimen of Umbrina cirrosa with $68.8 \mathrm{~cm}$ total length and $2600.00 \mathrm{~g}$ total weight was caught with handline by fisherman at a depth of $20 \mathrm{~m}$ (Figure 2). 


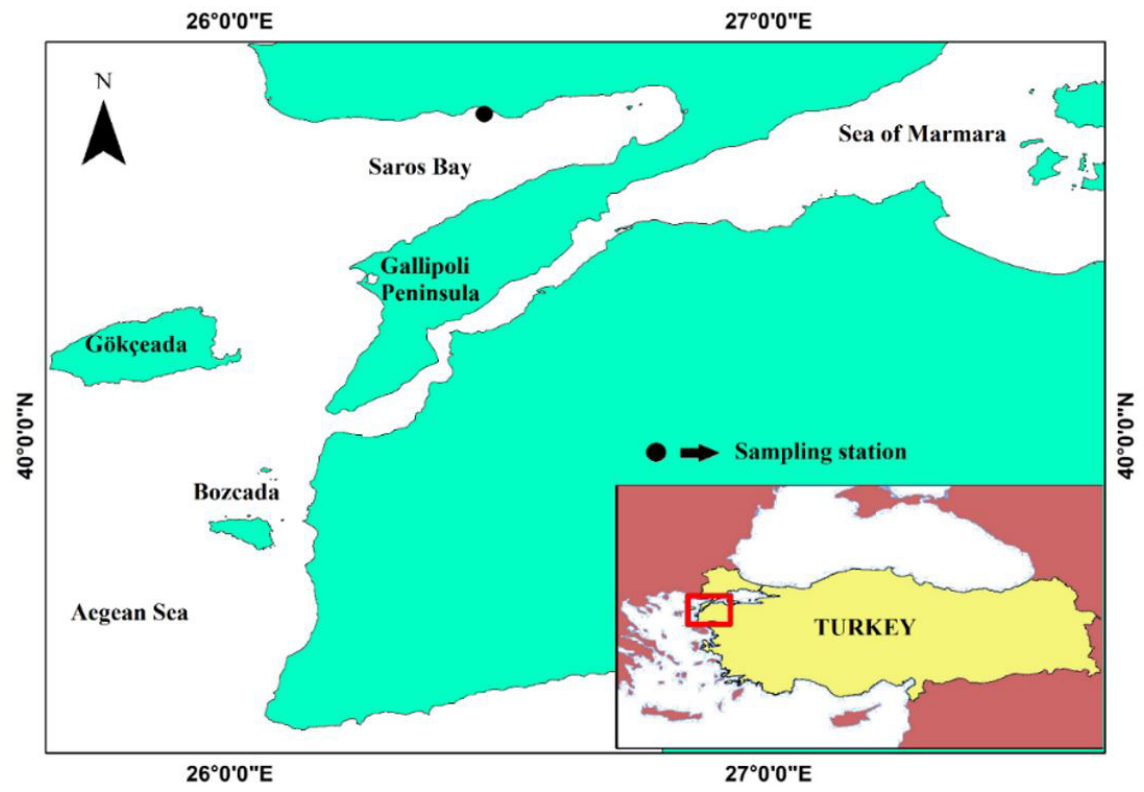

Figure 1. Bay of Saros and sampling station.

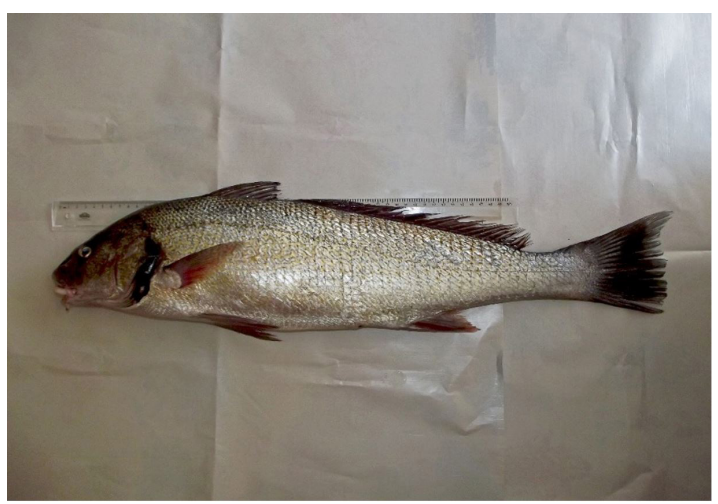

Figure 2. Umbrina cirrosa with $68.8 \mathrm{~cm} \mathrm{TL}$ and $2600.00 \mathrm{~g}$ TW from Bay of Saros.

Koutrakis and Tsikliras (2003) sampled nine specimens by using various fishing gear (beach-seine, fyke-net, gill nets) in Porto-Lagos lagoon (Northern Aegean Sea, Greece). They stated that the length range of the species was 6.5-24.7 cm (TL). Nevertheless, Froese and Pauly (2019) expressed the maximum size was $73.0 \mathrm{~cm}$ (TL) and maximum weight was $3100.00 \mathrm{~kg}$.

As well known, the individuals in populations exposed to high levels fishing pressure will respond by reproducing at smaller average sizes and ages and so reached maximum lengths may getting smaller. However, the one individual that subjected to no overfishing pressure could be reached that kind of length (Filiz, 2011). On the other hand, any factor that might possibly influence growth has been shown to have an effect, including nutrient availability, feeding, light regime, oxygen, salinity, temperature, pollutants, current speed, nutrient concentration, predator density, intra-specific social interactions and genetics (Helfman et al., 2009; Acarli et al., 2018).

In broad terms, the information on maximum length, weight, age, growth and weight-length relationship are required to estimate the population parameters as asymptotic length and growth coefficient of fish, which are essential for fisheries resource planning and management (Agureo et al., 2010). The information presented here may be used to compare the similar parameters in ongoing fishery studies all over the world by providing the scientific support to the fisheries scientists.

\section{Acknowledgements}

The authors would like to thank the fisherman Engin TUNÇ and Semih KALE for their supports.

\section{References}

ACARLİ, D., KALE, S. and ÇAKIR, K., 2018. A new maximum length for the garfish, Belone belone (Linnaeus, 1761) in the coast of Gökçeada Island (Aegean Sea, Turkey). Cahiers de Biologie Marine, vol. 59, no. 4, pp. 385-389.

AGUREO, J.D.L.C., GOMEZ, V.M.C. and NAVARRO, J.T.N., 2010. New maximum size record for the chili sea catfish Notarius troschelii (Siluriformes: Ariidae) from the Tropical Eastern Pacific. Marine Biodiversity Records, vol. 3, no. e107, pp. 1-3.

ANDERSON, R.O. and GUTREUTER, S.J. 1983. Length, weight, and associated structural indices. In: L. NIELSEN and D. JOHNSON, eds. Fisheries techniques. Bethesda: American Fisheries Society, pp. 283-300.

BORGES, L., 2001. A new maximum length for the snipefish Macrohamphosus scolopax. Cybium, vol. 25, pp. 191-192. 
CENGIZ, O., ISMEN, A. and OZEKINCI, U., 2014. Reproductive biology of the spotted flounder, Citharus linguatula (Actinopterygii: Pleuronectiformes: Citharidae), from Saros Bay (northern Aegean Sea, Turkey). Acta Ichthyologica et Piscatoria, vol. 44, no. 2, pp. 123-129. http://dx.doi.org/10.3750/AIP2014.44.2.06.

CENGIZ, O., OZEKINCI, U., ISMEN, A. and OZTEKIN, A., 2013. Age and growth of the four-spotted megrim (Lepidorhombus boscii Risso, 1810) from Saros Bay (Northern Aegean Sea, Turkey). Mediterranean Marine Science, vol. 14, no. 1, pp. 36-44. http:// dx.doi.org/10.12681/mms.328.

CENGIZ, O., OZEKINCI, U., ISMEN, A. and OZTEKIN, A., 2015. Some reproductive characteristics of four-spotted megrim (Lepidorhombus boscii Risso, 1810) from Saros Bay (Northern Aegean Sea, Turkey). Journal of Agricultural Sciences, vol. 21, no. 2 , pp. $270-278$.

DULČIĆ, J. and SOLDO, A., 2005. A new maximum length for the grey triggerfish, Balistes capriscus Gmelin, 1789 (Pisces: Balistidae) from the Adriatic Sea. Institute of Oceanography and Fisheries-Split Croatia, vol. 88, pp. 1-7.

ERONAT, C. and SAYIN, E., 2014. Temporal evolution of the water characteristics in the bays along the eastern coast of the Aegean Sea: Saros, İzmir, and Gökova bays. Turkish Journal of Earth Sciences, vol. 23, pp. 53-66. http://dx.doi.org/10.3906/ yer-1307-4.
FILIZ, H., 2011. A new maximum length for the red mullet, Mullus barbatus Linnaeus, 1758. Biyoloji Bilimleri Araştırma Dergisi, vol. 4, pp. 131-135.

FROESE, R. and PAULY, D., eds, 2019 [viewed 2 December 2019]. FishBase. World Wide Web Electronic Publication. version (08/2019) [online]. Available from: www.fishbase.org

HELFMAN, G.S., COLLATTE, B.B., FACEY, D.E. and BOWEN, B.W. 2009. The diversity of fishes: biology, evolution and ecology. 2nd ed. UK: Wiley-Blackwell, 720 p.

KOUTRAKIS, E.T. and TSIKLIRAS, A.C., 2003. Lengthweight relationships of fishes from three northern Aegean estuarine systems (Greece). Journal of Applied Ichthyology, vol. 19, no. 4, pp. 258-260. http://dx.doi.org/10.1046/j.14390426.2003.00456.x.

NAVARRO, M.R., VILLLAMOR, B., MYKLEVOLL, S., GIL, J., ABAUNZA, P. and CANOURA, J., 2012. Maximum size of Atlantic mackerel (Scomber scombrus) and Atlantic chub mackerel (Scomber colias) in the Northeast Atlantic. Cybium, vol. 36, no. 2, pp. 406-408.

SARI, E. and ÇAĞATAY, M.N., 2001. Distributions of heavy metals in the surface sediments of the Gulf of Saros, NE Aegean Sea. Environment International, vol. 26, no. 3, pp. 169-173. http:// dx.doi.org/10.1016/S0160-4120(00)00097-0. PMid:11341702. 